\title{
Effect of differentiated liming on the development of acidity of surface forest soil
}

\section{Podrázský}

Department of Silviculture, Faculty of Forestry and Wood Sciences, Czech University of Life Sciences Prague, Kamýcká 1176, 16521 Praha 6-Suchdol, Czech Republic,email:podrazsky@fld.czu.cz

\begin{abstract}
Podrázský, V. 2014: Effect of differentiated liming on the surface forest soil development. Beskydy, 7 (2): 99-106

Results obtained during 16 years of the experiment are presented. Extreme site conditions are determined by: $8^{\text {th }}$ vegetation altitudinal zone, podzolic soil and harsh climate - average annual temperature $4{ }^{\circ} \mathrm{C}$, average annual precipitation around $1200 \mathrm{~mm}$. Effects of surface experimental liming were studied on immission clear-cuts in long time period, study area is located on the Velká Deštná locality on the main Orlické hory Mts. range. Research plots were established in spring of 1988, studies of liming effects were performed in the period 1987-2004. On particular plots, 0, 1308, 2826, 3924 and $8478 \mathrm{~kg} / \mathrm{ha}$ of fine limestone (grain size under $1 \mathrm{~mm}$ ) was distributed by hands on the soil surface. Results are available for the forestry practice, research has to continue in the future - potential of negative liming impacts is topical here, consisting in humus mineralization and nutrients losses. Maximum effects on the soil reaction were observed in 8-10 years after limestone application at the soil surface (F- horizon) and in the period $10-15$ years lower (H, A - horizons). Base saturation dynamics shows the time delay 2-4 years following $\mathrm{pH}$ values changes.
\end{abstract}

Keywords: Immission areas, liming, soil chemistry, soil reaction, sorption complex

\section{Introduction}

Ameliorative liming was broadly used measurement in almost all Czech border mountains. It should improve the soil status and revitalize forest soils as well as forest stands in the immission areas with large scale forest decline. In the period 1978-2006 together 92,000 ha of forest land was limed (Kula, Menšík 2011, Kubelka et al. 1992, Šrámek et al. 2006). The uppermost part of the soil ecosystem compartment, i.e. the humus forms, is the most easily and profoundly subjected to the changes, both negative (degradation) or positive (revitalization). Also the management treatments are reflected in the shift of particular chemical, biological, as well as morphological soil characteristics (Green et al. 1993, Podrázský 2006a). Among others, the liming of forest grounds in the immission areas is an important factor, influencing the quality of the ecosystems dynamics (Podrázský et al. 2005, Podrázský 2006b, Šrámek et al. 2012). The duration of effects of liming treatments is a broadly discussed topic at the liming evaluation of forest soils and sites. The available results confirm relatively slight effects and their restricted duration. They were obtained on plots limed by the forestry practice, under non-controlled conditions, there is a lack of experimental results in the Czech region. Abroad, the information is much more complex, despite considerably different site, stand and generally ecological conditions (Bosch 1986, Popovic 1984, Huettl 1985).

The aim of the presented paper is so the documentation of outputs of a unique controlled experimental liming trial, evaluating the effects of dolomitic limestone application on the forest soil in concrete extreme site and immission conditions basing on the soil reaction 
dynamics. The case study enables the considering of liming effects on basic soil chemistry (soil reaction, $\mathrm{pH}$ ) in the uppermost horizons in a relatively long-term period.

\section{Material and methods}

Experimental plots were established in extreme site and ecological conditions of the Orlické Mts. (Czech-Polish border) close to the highest top (Velká Deštná, 1,115 m a.s.l., $8^{\text {th }}$ forest altitudinal zone). It is a crystalline part of the Czech Massif, the territory of the former Forest Enterprise Opočno, today Kolowrat Forests. Extremely unfavorable sites are conditioned by harsh climate (average annual temperature $4{ }^{\circ} \mathrm{C}$, average annual precipitation around $1,200 \mathrm{~mm}$ ), by the soils of podzol type and by elevated immission load in the past (decreased, by not without effects until today). At present, changed microand mezoclimatic conditions play also important role on extreme high elevation clear-cuts. Site type is characterized by the forest type 8Z2, rowan-spruce forest with Vaccinium myrtillus on slopes, geological bedrock is formed by schists. Soil type is by Morphogenetic classification system represented by Histic Podzols (PZo), in the ÚHÚL (Forest Management Institute) classification by grassy mountain podzol or peat podzol - at least at half of 80ies (Hraško et al. 1987, Němeček et al. 2001). Mineralization of surface humus was registered in the last period and the soil state needs reevaluation, the thickness of the surface layer dropping from $10-12 \mathrm{~cm}$ to $6-8 \mathrm{~cm}$ in 2004 . Research plot was established in the spring 1988 in growing 4-years old Norway spruce plantation, it included following variants: K-control, zero variant, without limestone application and then variants $3 \mathrm{H}, 3 \mathrm{~J}, 9 \mathrm{H}, 9 \mathrm{~J}$, representing use of 3 and 9 t.ha $^{-1}$ of coarse (H) or fine $(\mathrm{J})$ dolomitic limestone/dolomite from the pit Horní Lánov (21,5\% Ca, 11,25\% Mg). Coarse limestone was composed by $56.4 \%$ of mass of particles over $1 \mathrm{~mm}$, considered as without amelioration effects, then $15.6 \%$ of particles $1-0.5 \mathrm{~mm}, 11.1 \%$ of particles with size $0.5-0.2 \mathrm{~mm}$ and $16.9 \%$ less then $0.2 \mathrm{~mm}$. Corresponding share of fractions of the fine limestone was 5.8-16.3-20.4 and $57.5 \%$.

Liming was performed by hands evenly on the surface of particular sub-plots of $10 \times 10 \mathrm{~m}$ size, amount of particles less then $1 \mathrm{~mm}$ was in particular variants $(\mathrm{K}, 3 \mathrm{H}, 3 \mathrm{~J}, 9 \mathrm{H}, 9 \mathrm{~J}) 0$; 1,308; 2,826; 3,924 a 8,478 kg.ha-1. Soil samples were taken from horizons F, $\mathrm{H}$ and A (Ae or E types - uppermost $10 \mathrm{~cm}$ of mineral soil) in autumns of years 1987, 1988, 1990, 1992, 1994, 1998, 2002 and 2004. Basic soil survey was done by standard methods in 1987. On particular variants, there was taken 10 replications in 1988 and 1990, 5 replications in other years. In 1988, 1990, 2002 and 2004, the samples were analyzed individually, bulk samples were formed in other years from particular horizons. Non-dissolved limestone, both coarse as well as the fine, is still forming a distinct layer in the litter of the holorganic horizon, excluded from analyses (2004). From a wide spectrum of provided analyses by standard methods, results are documented of: soil $\mathrm{pH}$, soil adsorption complex characteristics by Kappen ( $\mathrm{S}$ - base content, $\mathrm{H}$ - hydrolytical acidity, $\mathrm{T}$ - cation exchange capacity, $\mathrm{V}$ - base saturation, exchangeable aluminum, total humus content, total nitrogen content by Kjehldahl, plant available nutrients in the citric acid solution/P - spectrophotometer, others AAS/, total nutrients content by AAS after minerelization by the sulphuric acid and selene). Analyses were provided in the laboratory Tomáš in the Forest Research Station Opočno (Podrázský 2006b). Only some of results (selected) are documented in this presentation as the most complex are documented the development trends of the soil reaction and base saturation.

\section{Results and discussion}

Results document visible effects of the performed liming on the studied pedochemical characteristics and clear development trends. As the most illustrative, the soil reaction, i.e. $\mathrm{pH}$ of the soil (humus forms particular layers), both actual and potential, was selected. Visible effects were documented since the first vegetation period in the fermentation (F) layer of the surface humus, as well as deeper, in the uppermost mineral horizon (Fig. 1, Fig 2). The differences in the uppermost holorganic horizon increased among variants in the next 6 years, then remained stable and decreased slightly in the 2002 (14 years since liming). They were still statistically significant between the variant 9J and other variants in 2004.

Lower differences and prolonged dynamics was observed in the H-layer., i.e. in the metamorphed holorganic horizon. In the mineral layer (of the Ae or E type), the effects of liming are observed only in the last periods (19942004). Bigger differences appear since 1994 
Tab. 1: Base saturation in particularhorizons in 2004 (\%).

\begin{tabular}{llllll}
\hline Variant & $\mathbf{K}$ & $\mathbf{3 H}$ & $\mathbf{3 J}$ & $\mathbf{9 H}$ & $\mathbf{9 J}$ \\
\hline Horizon & & & & & \\
\hline F & 66.0 & 65.8 & 73.9 & 76.1 & 87.5 \\
$\mathbf{H}$ & 38.6 & 43.4 & 40.7 & 45.2 & 78.3 \\
$\mathbf{A}$ & 25.2 & 27.1 & 27.8 & 26.4 & 51.3 \\
\hline
\end{tabular}

and only in the years 1998-2002 were registered in greater extent. The effect of liming was delayed in the lower horizons accordingly to dissolution of limestone and movement of the calcium deeper. The potential $\mathrm{pH}$ seems to react more prominently in the mineral horizon.

Base saturation did react with a time delay on the liming treatment (Tab. 1). In the F layer, the differences among variants increased in the period 1988-1998 and they start to decrease in the year 2002 (Podrázský 2006b). Differences are obviously lower comparing to soil reaction (Fig. 1, Fig 2). Differences in the base saturation are raising to the last sampling years in the lower horizons, the effects of increasing limestone amounts are obvious in the highest application only.

The previous results were published in the article of Podrázský (2006b). Liming affected also the active soil reaction $(\mathrm{pH}$ $\mathrm{H}_{2} \mathrm{O}$ ) significantly with the highest limestone amount in the year 2002. In the same way, the significant trends of base content (S-value) and cation exchange capacity (T-value) were increased and the exchangeable aluminum content slightly decreased by liming. The total $\mathrm{N}$ contents were higher in the Ah horizon of the more strongly limed plots - probably due to the relative enrichment and N-leaching in the lower horizons (Podrázský 2006b, Popovic 1984).

There are not comparable results of other authors in the literature. In the Czech countries, no other research team established such experiment. Moreover, the liming of immission clear-cuts was used only in the Czech Republic, so similar experiments were not studied abroad. This is why the discussion possibility is quite limited, despite this, results have high importance for the forestry practice - there are still ideas to use liming of clear-cuts on the regional scale.

Comparing to practical liming of immission clear-cuts, practiced in the 80ties of the last century and at the beginning of the current one, the controlled experimental liming did show much more observable effects (Kula, Menšík 2011, Kubelka et al. 1992, Šrámek et al. 2006). This was conditioned by the manual spread of the ameliorative material of the fine granulometric composition.

The use of the coarse limestone in the past could not show any profound effects (Peřina, Podrázský 1988, Podrázský 1989, Podrázský, Peřina 1989) because of the slow solubility of such a material, even slower using materials of dolomitic limestone/dolomite character. Laboratory and field experiments documented close relationship between the effects of the limestones and dimension of their grains. The effects were connected only with the grain size under $1 \mathrm{~mm}$, with an optimum between 0.2-0.5 mm (Podrázský 1990, Podrázský 1992). This was supported also with the more recent studies (e.g. Ulbrichová, Podrázský 2002). High attention has to be paid to the nitrogen dynamics as a potential hazard (Podrázský 2003). Also the local application at the plantation establishment coud be more effective (Kuneš et al. 2007a, 2007b, 2007c).

Very interesting is also the improved state of the humus forms even on the control plots, probably caused by the vegetation change (conifers replaced by grasses) and surely also due to the practical liming on the whole area of the Orlické hory Mts. main ridge. The question of the spontaneous soil restoration since the deposition lowering is problematic.

\section{Conclusions}

Liming in controlled conditions shows visible and clear effects on the soil chemistry. Obtained results enable several important conclusions from the viewpoint of the further strategy of the liming use in similar conditions: - liming and its effects need further complex research to consider its importance and to prevent the negative impacts, especially on immission clear-cuts and in young plantations, 
Horizon F

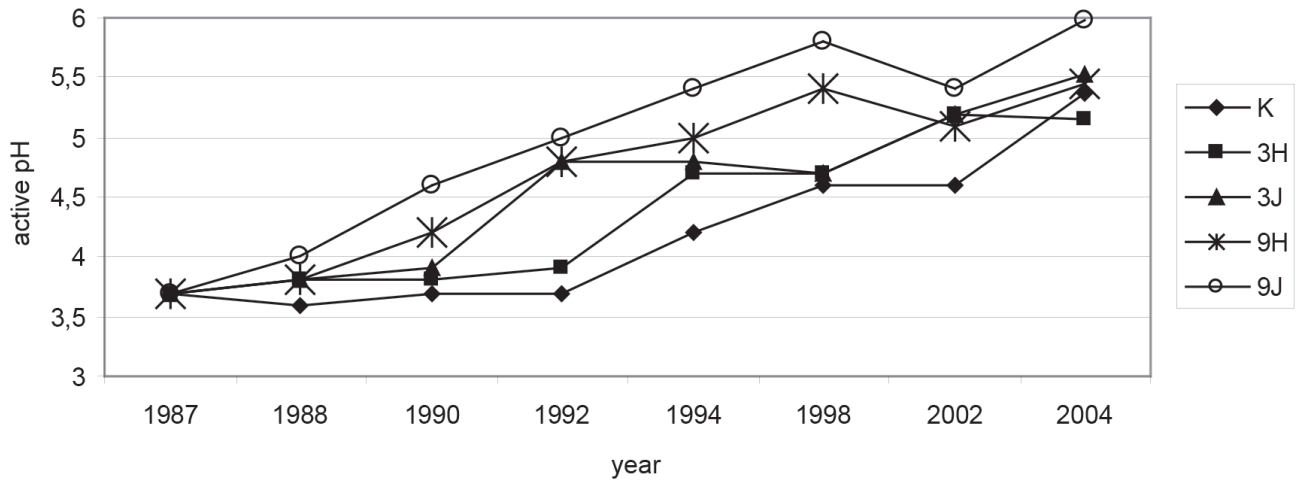

Horizon $\mathrm{H}$

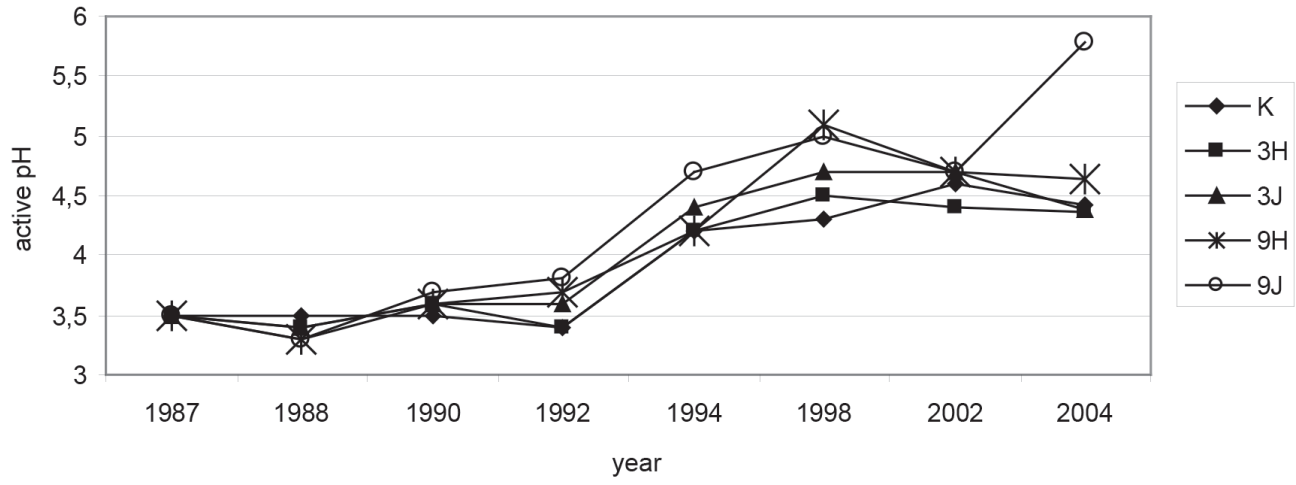

Horizon A

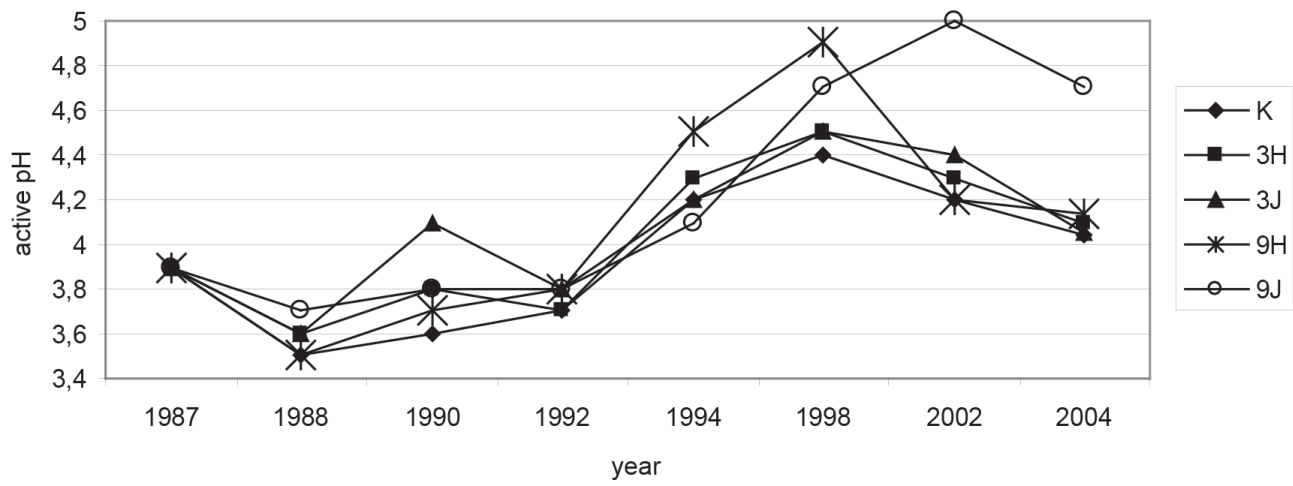

Fig. 1: Dynamics of the active soil reaction $\left(\mathrm{H}_{2} \mathrm{O}\right)$ until the year 2004. 


\section{Horizon F}

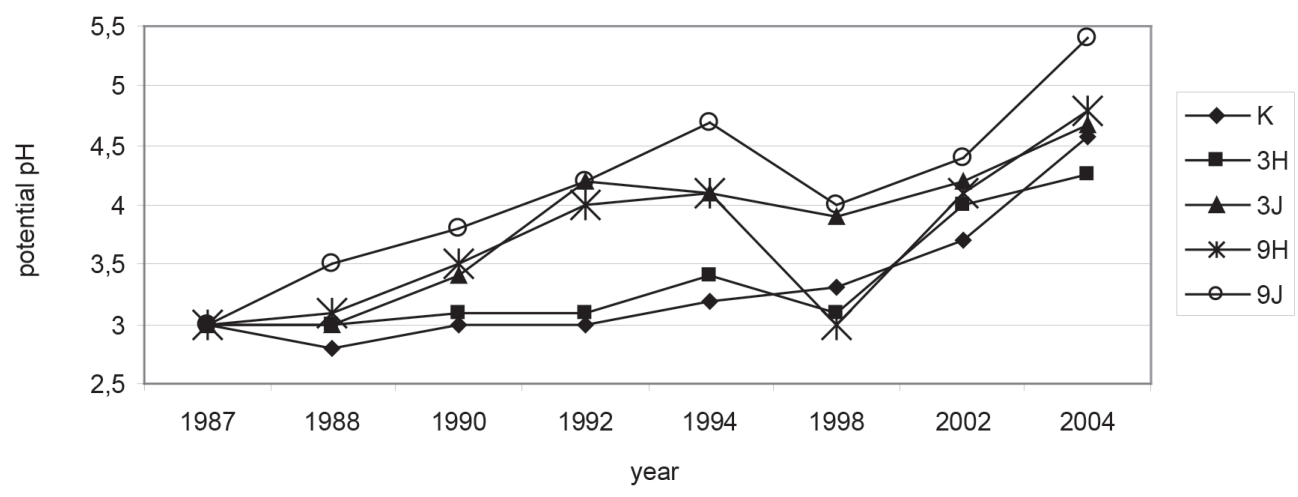

Horizon $\mathrm{H}$

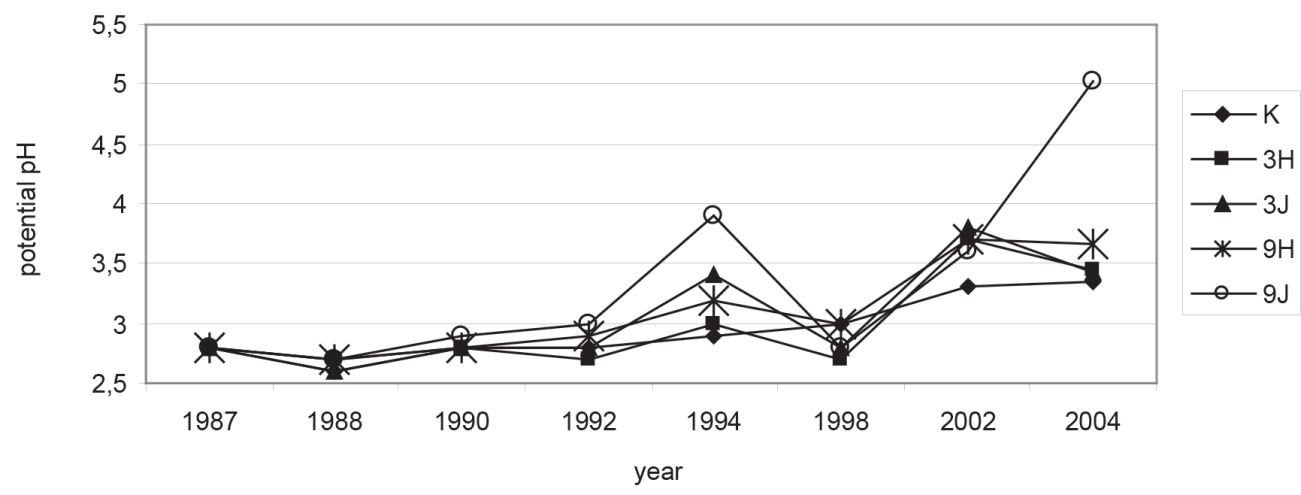

Horizon A

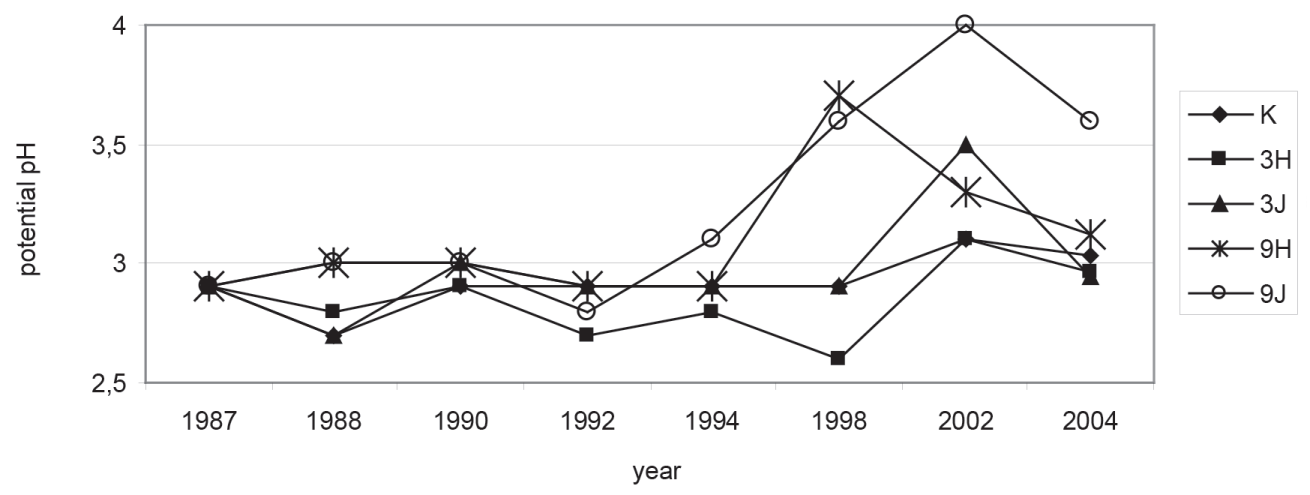

Fig. 2: Dynamics of the potential soil reaction (1N KCl) until the year 2004. 
- liming has visible effects on the changes of selected pedochemical characteristics in the uppermost soil layers,

- at surface application of limestone, the maximum effects on soil reaction $(\mathrm{pH})$ are observable in the uppermost layers of the surface humus in the period 8-10 years, deeper (H, A, E horizons) in the period 10-15 years,

- intensity of changes in the soil adsorption complex characteristics follows the soil reaction in 2-5 years,

- only the fine (under $1 \mathrm{~mm}$ ) fraction of the limestone is effective,

- to minimize unfavorable liming effects, the rapid establishment of effective tree shelter (both preparatory and climax species) is desirable.

Note: Research was funded by the institutional programmes.

\section{References}

Bosch, C. 1986: Standorts- und ernährungskundliche Untersuchungen zu den Erkrankungen der Fichte Picea abies (L.) Karst. in höheren Gebirgslagen. Forstliche Forschungsberichte, 75, München, 241 pp.

Green, R. N., Trowbridge, R. L., KLinKa, K. 1993: Towards a taxonomic classification of humus forms. Forest Science, 39: Monograph Nr. 29, Supplement Nr. 1, 49 pp.

HRAŠKo, J. et. AL. 1987: Morfogenetický klasifikačný systém pôd ČSSR [Morphogenetic classification soil system of the Czech Republic]. Bratislava, ČSAV, 107 pp.

HuettL, R. 1985: „Neuartige“ Waldschäden und Nährelementversorgung. Freiburg im Breisgau, Institut für Bodenkunde und Waldernährungslehre, $195 \mathrm{pp}$.

Kubelka, L., KarÁsek, A., Rybář, V., Badalík, V. 1992: Obnova lesa v imisemi poškozované oblasti východního Krušnohoři [Forest Regeneration in Area Damaged by Air Pollution in NE Krušné hory Mts.] Praha, MZe: 133 pp.

Kuneš, I., Balcar, V., Zahradník, D. 2007a: Vliv cílené povrchové aplikace dolomitického vápence na pedochemické parametry půdy na imisní holině ve vrcholových partiích Jizerských hor [Influence of precisely applied liming on chemical properties of soil in clear-felled area located in highest elevation of air polluted mountains (the Jizerské hory Mts.)]. Zprávy lesnického výzkumu, 52: 234-245.

Kuneš, I., Balcar, V., Vykypělová, E., Zadina, J., Šedlbauerová, J., Zahradník, D. 2007b:
Vliv jamkové a pomístné povrchové aplikace dolomitického vápence na množství a chemické složení biomasy smrku ztepilého v Jizerských horách [Effects of planting hole application or spot surface application of finely ground dolomitic limestone on amount and chemical composition of biomass of Norway spruce in the Jizerské hory Mts.]. Zprávy lesnického výzkumu, 52: 316-327. Kuneš, I., Balcar, V., Zahradník, D. 2007c: Influence of a planting hole application of dolomitic limestone powder and basalt grit on the growth of Carpathian birch (Betula carpatica W. et K.) and soil chemistry in the airpolluted Jizerské hory Mts. Journal of Forest Science, 53: 505-515.

Kula, E., Menšík, L. 2011: Earthworms (Lumbricidae) of an air-polluted area affected by ameliorative liming. Journal of Forest Science, 57: 210-218.

NěMeČek, J., Mackủ, J., Vokoun, J., VavŘ́čče, D., NovÁk, P. 2001: Taxonomický klasifikační systém půd České republiky. [Taxonomic classification system of soils of the Czech Republic]. Česká zemědělská univerzita a VÚMOP, Praha. 79 pp.

PeŘInA, V., PoDRÁZsKÝ, V., 1988: Účinnost vápnění v Jizerských horách [Liming effects in the Jizerské hory Mts.]. Lesnická práce, 67: 12-17.

PoDRÁZsKÝ, V. 1989: Vliv vápnění na chemické vlastnosti lesních půd Jizerských hor, Orlických hor a Krkonoš [Liming effects on chemical soil characteristics of the Jizerské hory, Mts., Orlické hory Mts. and Krkonoše Mts.] Práce VÚLHM, 74: 169-205.

PoDrÁZsKÝ, V. 1990: Relativní účinnost zrnitostních frakcí dolomitického vápence v laboratorních podmínkách [Relative effectiveness of grain fractions of the dolomitic limestone in laboratory conditions]. Zprávy lesnického výzkumu, 35: 15-18.

PodRÁZsKÝ, V. 1992: Dolomitický vápenec složení a účinnost [Dolomitic limestone composition and effectiveness]. Zprávy lesnického výzkumu, 37: 36-39.

Podrázský, V., Peřina V. 1989: Zahraniční zkušenosti s vápněním lesních půd [Foreign experiences with liming of forest soils]. Lesnická práce, 68: 111-120.

PoDRÁZSKÝ, V. 2003: Velkoplošné povrchové vápnění imisních holin: rizika a přínosy [Large-scale liming of immission clear-cuts: risks and benefits]. In: Využití chemické meliorace v lesním hospodárství ČR. ČZU v Praze, Kostelec nad Černými lesy, 60-65.

PodrÁZsKÝ, V. 2006a: Fertilization as an ameliorative measure - examples of the research 
at the Faculty of Forestry and Environment CUA in Prague. Journal of Forest Science, 52, Special issue, 58-64.

PODRÁZSKÝ, V. 2006b: Effect of controlled liming on the soil chemistry on the immission clear-cut. Journal of Forest Science, 52, Special issue, 28-34.

PodrÁZskÝ, V., VAcek, S., Remeš, J., Ulbrichová, I. 2005: Application of Mg-fertilizers to prevent and to decrease Norway spruce yellowing. Journal of Forest Science, 51, Special Issue, 43-48. Popovic, B. 1984: Mineralization of carbon and nitrogen in humus from field acidification studies. Forest Ecology and Management, 8: 8-94.

ŠrÁmeK, V., Materna, J., NovotnÝ, R., FadrhonsOVÁ, V. 2006: Effect of forest liming in the Western Krušne hory Mts. Journal of Forest Science (Special Issue), 52: 45-51.

ŠrámeK, V., FAdrhonsová, V., Vortelová, L., LomSKÝ, B. 2012: Development of chemical soil properties in the western Ore Mts. (Czech Republic) 10 years after liming. Journal of Forest Science, 58: 57-66.

UlbrichovÁ, I., PODRÁzsKÝ, V. 2002: Dlouhodobé účinky povrchového vápnění na stav kultur smrku a lesní půdy [Long-term effects of the surface liming on the spruce plantation status and on forest soils]. In: Výsledky lesnického výzkumu v Krušných horách v roce 2001, VÚLHM, Teplice, 29-36. 
